\title{
Evaluation of Complications Followins Impacted Mandibular Third Molar Extraction in Patients with Different Hand Preference
}

\author{
Farklı El Tercihi Olan Hastalarda Mandibu"ar Garm \\ Üçüncü Molar Çekim Sonrası Oluşan Komprm \\ Değerlendirilmesi.
}

\author{
(1) Utkan Kamil Akyol, (1) Neziha Keçecios
}

Recep Tayyip Erdoğan University Faculty of Dentistry, Department of Oral, Dental, Chin Dise ses am argery, Rize, Turkey

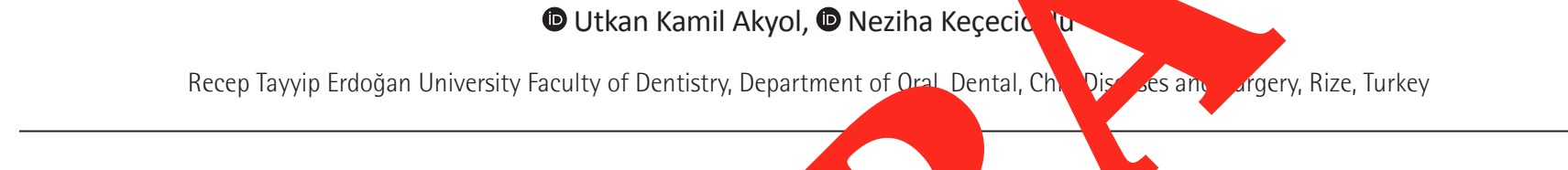

Abstract

Objective: Indivia

ring right or left hand for doing various hand workinas, is the It was amony or left hand dominant individuals, there is an im unologicar try, an a difference in motor control, visuospatial skills, and

Keywords

Functional laterality, impacted, tooth extraction

incidence try, an a difference in motor control, visuospatial skills, and
number of disease. The aim of the study was to investigate pain, a, trism following the mandibular third molar extraction in patients with di. hanc preference.

aterials Methods: Forty-three patients who were indicated for bilateral Anahtar Kelimeler Fonksiyonel lateralite, gömülü, d: ical extre cion of impacted mandibular third molars were included in the study. i. 30 a The patients were divided into four groups; 1) left handed-right (right thirc molar), 2) left handed-left, 3) right handed-right, and 4) right handed-left. easurements were made for comparison of pain, edema and trismus before and after operation.

Results: The statistical significance was not observed between the groups regarding the pain, edema and trismus ( $p>0.05)$.

Conclusion: The results suggest that severity of pain, edema and trismus may not be related to the hand preference following the right and left mandibular third molar extraction. Extended studies demonstrating an extent of an influence of hand preference in the complications of oral surgery, could be useful for planning the surgical interventions as well as for treatment results in maxillofacial surgery.

Öz

Amaç: Bireyin çeşitli el işlerini yapmak için sağ veya sol elini tercih etmesi serebral lateralizasyonun en kolay gözlenebilen şeklidir. Sağ veya sol eli dominant olan kişiler arasında motor kontrol, vizyospasyal görevleri yerine getirmede, çeşitli hastalıkların görülme insidansında farklılıklar ve immün asimetri olduğu söylenmiştir. Bu çalışmada, mandibular 3. molar çekimini takiben görülen ağrı, ödem, trismusun el tercihi farklı olan hastalarda değerlendirilmesi amaçlanmıştır. 
Gereç ve Yöntemler: Çalışmaya, sağ ve sol mandibular gömülü 3. molar dişlerin çekiminin gerekli olduğu 43 hasta dahil edildi. Aynı hastadan sağ ve sol mandibular gömülü diş çekimi 30 gün arayla yapıldı. Dört hasta grubu oluşturuldu: 1) el tercihi sol-sağ (sağ mandibular 3. molar dişi çekilen), 2) el tercihi sol-sol, 3) el tercihi sağ-sağ, 4) el tercihi sağ-sol. Ağrı, ödem ve trismusun operasy $\bigwedge_{\text {ndan }}$ önce ve sonra karşılaştırılması için ölçümler yapıldı.

Bulgular: Gruplar arasında ağrı, ödem, trismus açısından istatistiksel bir fark görülmedi $(p>0,05)$.

Sonuç: Sonuçlar, sağ ve sol mandibular üçüncü molar ekstraksiyonu sonrası ağrı, ödem ve trismus şiddetinin el tersihi_ile ilișkilı olmayabileceğini düşündürmektedir. Fonksiyonel serebral lateralizasyon olan el tercihinin oral cerrahi komplikasyo

etkin olduğunu ortaya çıkaracak daha kapsamlı araştırmaların gerek maksillofasiyal cerrahi girişimlerinin plapłanmà nda gereks tedavi sonuçlarında faydalı olabileceği kanaatine varılmıştır.

\section{Introduction}

Extraction of impacted mandibular third molars is among the commonly performed procedures in oral surgery. Complications such as pain, edema, and trismus may occur after extraction. The severity of these complications depends on how embedded the extracted tooth is, its anatomical position, its adjacencies, and gum inflammation, in addition to the patient's systemic diseases, pre-and postoperative oral hygiene, and immune resistance (1-5).

Hand preference is defined as choosing the right or left hand to perform various manual tasks such as writing and using a fork and knife.

lateralization is the anatomical and foctiona differentiation between the right and left $r$ heres of the brain. The right and left herisphe, ve separate functions, and the domi hemis, performs these functions better than ther (6There is a direct relationship bo veen har ferenc. and right- or left-hemispm and preference is functional rebra alizatio and is the most easily obs ved manifes of cerebral lateralization $(8,9)$ s have revea differences in motor contro perfo ce of visuospatial tasks, and the inci ence of vario seases between righthanded a. handed indiv als (10-12).

Sey ral stu have evaluated the complications that oc ur follow npacted mandibular third molar tractio in differo satient groups $(13,14)$. In this con plication of impacted mandibular third mo 'ar tion, such as pain, edema, and trismus, wer comp ed in patients with different hand ences.

\section{Materials and Methods}

A total of 43 patients between 17 and 43 years old with a mean age of 21.6 years were included in the study. The group comprised 11 (25.5\%) males and
32 (74.4\%) females. All patients in the study required extraction of th left and hio nandibular third molars [class 2, pu ertically-impacted according to the Pell and Gregu sification System (15)] with bone removal. Patients wno were pregnant or had syster smoking habit, allergy to any of the drus 's a nostoperatively, history of antibiotic or na'sesic se in the last month, or inf acute $p$ ricororitis, and severe periodontal diseas the oper tion site were not included.

All were informed about the surgical qure possible complications. The study pro was reviewed and approved by the Recep Tayyip doğan University Faculty of Medicine nical Research Ethics Committee (meeting date: 10.2015, decree no: 37). Panoramic radiographies f all patients were obtained preoperatively. Each patient's name, age, gender, and the classification of impacted teeth were recorded in a patient follow-up form. Patients provided informed consent by signing a volunteer consent form which including brief information about the study.

The procedures were performed under mandibular and buccal local anesthesia. Following an L-type incision, a full-thickness flap was lifted. The bone tissue around the tooth was removed under flow of a physiological saline solution. Also, after extraction of the tooth, the cavity was irrigated with physiological saline solution. The wound was closed with a primary 3-0 silk suture. All the extractions were done by the same surgeon. Forty-three patients with different hand preferences whose impacted mandibular right and left third molars needed to be extracted were included in the study. Eleven of the patients were lefthanded and 32 were right-handed. For data analysis, 4 groups were created: 1) Left hand preferenceright extraction ( $n=11) ; 2$ ) Left hand preference-left extraction $(n=11)$; 3$)$ Right hand preference-right 
extraction ( $n=32)$; 4) Right hand preference-left extraction $(n=32)$. For all patients, there was a 30 day interval between extractions of the right and left impacted mandibular third molars, and a total of 86 teeth were extracted.

An antibiotic (amoxicillin $500 \mathrm{mg}$ twice daily), analgesic (paracetamol $500 \mathrm{mg} 3$ times daily), and mouthwash ( $2 \%$ chlorhexidine gluconate 3 times daily) were prescribed postoperatively. Patients were advised by a physician postoperatively to not eat or drink for 2 hours after surgery, to avoid hot food and drinks within the first 24 hours, to not chew with the area involved in the operation, to eat soft and warm foods, to brush normally in the unoperated areas, to avoid touching the teeth, stitches, and gums in the surgery area while brushing, to use the prescribed mouthwash twice a day, after brushing their teeth in the morning and evening, and to not eat or drink anything for 1 hour after using the mouthwash. For all patients, sutures were removed on the $7^{\text {th }}$ postoperative day.

\section{Collection of Data Before and After Extraction}

The visual analogue scale (VAS) was used to pain in the study. VAS scores (0-10 poir \$) were evaluated at postoperative 2,6 , and 12 nd 2 , 4 , and 7 days.

We modified the method desc by Sch Mosgau et al. (16) to assess exlema the face: 6 fixed points and 5 rgical b marked on the patient's face closed, and the distan was measured using a s. Measuren mere made immediately befo e ry and at 2 , and $7^{\text {th }}$ days postoperatively. he su all measurements was taken as far size. The am at and $7^{\text {th }}$ days was ylated for eac patient by subtracting the pr operat se size (sum of preoperative facial measur ments) the postoperative face size ms of acial meas ements taken at postoperative 4. das, respectively).

To te trismus, the distance between the 'ow $r$ and upper right central teeth were measured millimetric ruler before the surgery and at $2^{\text {nd }}$ and days after surgery. The difference between preoperative and postoperative measurements was recorded as the amount of trismus on the given day.

Hand preference was determined using the Edinburgh Handedness Inventory (8). Those with handedness scores lower than zero were considered as left-handed and those with scores higher than zero were considered right-handed.

\section{Statistical Analysis}

The Mann-Whitney $U$ and Wilcoxon tests were used for statistical analysis of the data than 0.05 was considered statistical' signı 'ant.

\section{Results}

According to VAS scores, an had similar high levels of pain at $2 b$ urs, $6 \mathrm{~h}$ urs, days after extraction. VAS scores ad t 4 days and were lowest on day 7 . There was in stically significant difference between groups in terms of postoperative VAS values $(p$.

There was ro significant difference ( $p>0.05$ ) betwee gre aps, en postoperative 2 and 7 da na and tr mus values were compared.

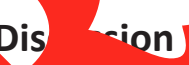

$\eta$, eucm..., and trismus after the extraction of imp third molars are expected outcomes and hese riplications adversely affect the daily life of tients (17-19). Many studies have suggested that rticosteroids, different anesthetics, pain killers, nd anti-inflammatory drugs may reduce the severity of these complications $(20,21)$. It has been claimed that post-extraction pain reaches maximum intensity within 2-4 hours or, according to some studies, within 12 hours, and that the pain level decreases on postoperative day 6 (17-21). We did not find any studies on oral surgery in patients with different hand preferences in the literature. In our study, we found that pain was high in all groups at 2 hours, 6 hours, and 2 days after extraction, decreased on day 4 , and reached its lowest level on day 7 . There was no statistically significant difference between the groups in terms of VAS scores ( $p>0.05$ ). Furthermore, there was no statistical difference in the VAS values after impacted right and left mandibular third molar tooth extraction, regardless of hand preference. In their study on cerebral lateralization, Pauli et al. (22) stated that right hemisphere hyperactivity causes increased pain sensitivity and that pain sensitivity may vary according to hemisphere dominance. The level of pain after the removal of an impacted tooth may vary from patient to patient. Therefore, 
we conducted our study in patients undergoing extraction of symmetrical impacted third molars with similar difficulty level to allow the comparison of postoperative pain on both sides in the same patients. Our study group also included patients with different hand preference. As hand preference known to be a functional cerebral lateralization, we concluded that cerebral lateralization does not create a difference in terms of pain intensity after impacted mandibular third molar extraction.

Pain is one of the most important causes of trismus after mandibular third molar extraction. Other causes of trismus include postoperative edema, inflammation, hematoma, muscle and tendon trauma, and psychological components (19-21). Trismus reaches its maximum level 2 days after extraction and may last for 7-10 days (21). It has been claimed that the duration and severity of this complication varies from patient to patient (17-21). In our study, there was no statistically significant difference between groups when the levels of trismus at postoperative 2 and 7 days were compared. We observed that trismus was severe on day 2 in all groups and decreased

7 , consistent with the results of other stud s in the literature (17-21) Similarly, no statistical ificant difference was found between grour $s$ in eu at postoperative 2 and 7 days.

Severe trismus can cause secon by making the maintenance after extraction, thus increasi postoperative complic (2) horeove, poor oral hygiene after $f$ raction can a infease the severity of trism s. uperiority o ight- or lefthanded patiens in $\mathrm{m}$ ining oral hygiene is a subject of $d$ ate. In a stud, atients with different hand prese. $s$, it was rep ed that right-handed patier sract, etter oralnygiene and had a lower incidence of deca npared to left-handed patients 11) The are also udies that state the opposite to He rmann and van Dyke (28) found that lefthal deu acts were faster than the right-handed -ubj cts in evaluating the same or different sensory ns presented in various orientations. Studies have. used on the possibility that patient motivation, manual dexterity, and tooth brushing efficiency may differ in right-handed and left-handed individuals and, therefore, have lead to differing conclusions regarding whether postoperative inflammation and the maintenance of oral hygiene are associated with handedness (29).

There are also studies in the literature showin that there is a relationship between hand preference and various diseases. Type 2 diabetes and autoimmune and inflammatory diseases are some $o$ whose incidence differs between right and terthanded individuals $(30,31)$. Som studio have reported that the immune stem stronge on the left side of the body a (32-34). There is a dire thelat in tween the immune system and mmation. Im mediators released during inflamm get immune and inflammatory cells (35). The sev of complications such as pain, dema, and trismus arter extraction is affected by th the of inflammation at the site extraction (19-27). So ammation may increase the developmen of -ompl ations after extraction (19$2-1$. study, tore was no statistical difference in the pa edema, a trismus values after extraction ve groupu and 2, suggesting that there was also no a. nnce in inflammation in the extraction areas. ecent adies have focused on whether the number, e, and ultrastructural features of lymph nodes on e left and right sides of the body are different in ndividuals with different hand preferences (36-38).

One study stated that cerebral lateralization influences facial structure, with the right craniofacial region being larger than the left in right-handed people, and the left craniofacial region being larger than the right in left-handed people (39). The authors of another study emphasized that facial asymmetry was less pronounced in left-handed individuals compared to right-handed individuals (40). Research is also being conducted on whether this asymmetry influences chewing strength and whether there is a right or left chewing side preference in individuals with different hand preferences (41).

\section{Conclusion}

Our results show that the severity of complications such as pain, edema, and trismus that occur after mandibular third molar extraction may not be related to hand preference. There was no statistically significant difference in pain, edema, and trismus severity after impacted mandibular right and left third molar extraction between patients with different hand 
preferences. More extensive research elucidating the impact of hand preference, which is a functional measure of cerebral lateralization, on oral surgery complications may be beneficial both in the planning of maxillofacial surgical interventions and in achieving favorable treatment outcomes.

\section{Ethics}

Ethics Committee Approval: The study protocol was reviewed and approved by the Recep Tayyip Erdoğan University Faculty of Medicine, Clinical Research Ethics Committee (meeting date: 23.10.2015, decree no. 37).

Informed Consent: Informed consent was obtained from all patients.

Peer-review: Externally peer-reviewed.

\section{Authorship Contributions}

Surgical and Medical Practices: U.K.A., Concept: U.K.A., Design: U.K.A., Data Collection or Processing: U.K.A., N.K., Analysis or Interpretation: U.K.A., Literature Search: U.K.A., N.K., Writing: U.K.A.

Conflict of Interest: No conflict of interest was declared by the authors.

Financial Disclosure: The authors declar a tm this study received no financial support.

\section{References}

1. Al-Moraissi EA, Elmansi YA, Al-Sharaee YA, AS. Does the piezoelectric surgic techniqu postoperative sequelae after conventional rotary instruments? analysis. Int J Oral Maxill acs 201

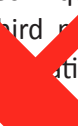

2. Arteagoitia MI, Barb Santamaría J, la G, Ramos atic revie

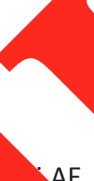
. Alkhi uce fewt v than meta E. Efficacy of ar ox and amoxicillin vulanic acid in the prevention infec d dry sockel after third molar extraction syst matic re nd meta-analysis. Med Oral Patol or Pucal 2016; 21: e.

3. Fishar SE, $\quad W$, Rout PG, $M$ - -ntegart DJ. Factors affecting the nset and ty of pain following the surgical removal of un ateral impa dibular third molar teeth. Br Dent J 1988; 1 4: 351-4.

rif Montebugnoli L, Vaccaro MA. Extraction of impacted thins. A longitudinal prospective study on factors that ffect pos erative recovery. Oral Surg Oral Med Oral Pathol 1 94; 77: 341-3.

mae-Saar J, Leibur E, Tamme T. The effect of prednisolone on vduction of complaints after impacted third molar removal. Stomatologija 2010; 12: 17-22.

6. Leong CK. Confessions of a schoolman-On dyslexia and laterality. Ann Dyslexia 1984; 34: 15-27.

7. Pençe S. Serebral Lateralizasyon. Van Tıp Dergisi 2000; 7: 120-25.
8. Coren S, Halpern DF. Left-handedness: a marker for decreased survival fitness. Psychol Bull 1991; 109: 90-106.

9. Soysal AS, Ayhan E, Aktürk A, Can H. El Tercihi ve El Tercihini Belirleyen Etkenler. Türkiye Çocuk Hastalıkları Dergisi 20 7; 1 : 60-8.

10. Annett M. Predicting combinations of left and right acummetries. Cortex 2000; 36: 485-505.

11. Henderson NJ, Stephens CD, Gale D. Left landea 'ss in dental undergraduates and orthodontic speciarist. Br Dent $996 ; 181$ : 285-8. 12. Yıldırım S, Dane S. Cerebral Lat
Eurasian J Med 2007; 39: 45-8.

13. Barbalho JC, Vasconcello de Mor is Hh, s LA, Almeida RA, Rêbelo HL, et al. adm histered de, amethasone and nimesulide on pain, swem, rismus following third molar surgery: a randomized, tripin d, controlled clinical trial. Int J Or Maxillofac Surg 2017; 46: 236-42.

14. Prajapati A, Sathaye $S$. Benefits of not Prescribing Prophylactic A tion Third Molar Surgery. J Maxillofac Oral Surg 2016; 5: $21-20$.

15 Gregory G Report ch a ten-year study of a tooth division te ue for the r moyal of impacted teeth. Am J Orthod 1942; 28: 1 Sch Schmelzeisen R, Frölich JC, Schmele H. Use ibuprolernand methylprednisolone for the prevention of d swelling after removal of impacted third molars. J Oral

Ma. Surg 1995; 53: 2-7. Ustï, Y, Erdogan O, Esen E, Karsli ED. Comparison of the effects of 2 doses of methylprednisolone on pain, swelling, and trismus after third molar surgery. Oral Surg Oral Med Oral Pathol Oral Radiol Endod 2003; 96: 535-9.

18. McGrath C, Comfort MB, Lo EC, Luo Y. Changes in life quality following third molar surgery--the immediate postoperative period. Br Dent J 2003; 194: 265-8.

19. Kim K, Brar P, Jakubowski J, Kaltman S, Lopez E. The use of corticosteroids and nonsteroidal antiinflammatory medication for the management of pain and inflammation after third molar surgery: a review of the literature. Oral Surg Oral Med Oral Pathol Oral Radiol Endod 2009; 107: 630-40.

20. Jerjes W, Upile T, Kafas P, Abbas S, Rob J, McCarthy E, et al. Third molar surgery: the patient's and the clinician's perspective. Int Arch Med 2009; 2: 32.

21. Joshi AD, Saluja H, Mahindra U, Halli R. A comparative study: efficacy of tissue glue and sutures after impacted mandibular third molar removal. J Maxillofac Oral Surg 2011; 10: 310-5.

22. Pauli P, Wiedemann G, Nickola M. Pain sensitivity, cerebral laterality, and negative affect. 1999; 80: 359-64.

23. Peñarrocha M, Sanchis JM, Sáez U, Gay C, Bagán JV. Oral hygiene and postoperative pain after mandibular third molar surgery. Oral Surg Oral Med Oral Pathol Oral Radiol Endod 2001; 92: 260-4.

24. Cakur B, Yıldız M, Dane S, Zorba YO. The effect of right or left handedness on caries experience and oral hygiene. J Neurosci Rural Pract 2011; 2: 40-2.

25. Coren S, Porac C. Fifty centuries of right-handedness: the historical record. Science 1977; 198: 631-2. 
26. Addy M. Tooth brushing, tooth wear and dentine hypersensitivity-are they associated? Int Dent J 2005; 55(4 Suppl 1): 261-7.

27. Tezel A, Orbak R, Canakci V. The effect of right or left-handedness on oral hygiene. Int J Neurosci 2001; 109: 1-9.

28. Herrmann DJ, van Dyke KA. Handedness and the mental rotation of perceived patterns. Cortex 1978; 14: 521-9.

29. Özgöz M, Arabaci T, Sümbüllü MA, Demir T. Relationship between handedness and toothbrush-related cervical dental abrasion in left- and right-handed individuals. J Dent Sci 2010; 5: 177-82.

30. Bonnet F, Affret A, Boutron-Ruault MC, Balkau B, ClavelChapelon F, Fagherazzi G. Association Between Handedness and Type 2 Diabetes: The E3N Study. Diabetes Care 2015; 38: e199.

31. Ertunç V, Dane S, Karakuzu A, Deniz O. Higher herpes zoster infection frequency in right-handed patients and more frequent appearance in the left body side of females. Acta Derm Venereol 1997; 77: 245.

32. Geschwind N, Behan P. Left-handedness: association with immune disease, migraine, and developmental learning disorder. Proc Natl Acad Sci U S A 1982; 79: 5097-100.

33. Battcock TM, Finn R, Barnes RM. Observations on herpes zoster: 1. Residual scarring and post-herpetic neuralgia; 2 . Handedness and the risk of infection. Br J Clin Pract 1990; 44: 596-8.

34. Tan U. The distribution of hand preference in normal men and women. Int J Neurosci 1988; 41: 35-55.
35. Kuralay F, Çavdar Z. Inflamatuar medyatörlere toplu bir bakış. Genel Tıp Derg 2006; 16: 143-52.

36. Demirel H, Bahar A, Gokgoz N, Arslan M, Dane S. Right sided lateralization of skin temperature in healthy young pers om Clin Invest Med 2016; 39: 27515.

37. Sumner RC, Nowicky AV, Parton A, Wylock Ccoriesi R, Fischler B, et al. Prospective relationship be lateralisation and CD4+ T cells in human in munoa ficiency virus type 1. Neuroimmunomodulation 2014, 2. 31-6.

38. Mc Manus IC, Bryden MP. The gen fics of ho dedness, a rebral dominance and lateralization 'owitz Vapinn I, as. Handbook of Neurophysiology, $v$ r, Amsterdam, 1992; p.115-45.

39. Rovira-Lastra B, Flores Ay so-Monter R, Peraire M, Martinez-Gomis J. Perip ctional and postural asymmetries related to the preferrean ing side in adults with natural den 'คn. J Oral Rehabil 2016; 43: 279-85.

40. Frayne $E, C d$ Adams R, Croxson G, Waddington G. Laterality of ropm in the orofacial muscles and temporomandib lar i int. osci Lett 2016; 635: 111-6.

41 Lastra B, ores-Orczco El, Ayuso-Montero R, Peraire Ml, rtinez-Gom J Peripheral, functional and postural asyn etries related 0 the preferred chewing side in adults with Oral Rehabil 2016; 43: 279-85. 